\title{
Study of the karyotype of Oryzoborus maximiliani (Passeriformes - Aves) using young feather pulp cultures
}

\author{
Beatriz Goldschmidt ${ }^{1}$, Denise Monnerat Nogueira ${ }^{2}$, Katia Pacheco Araujo Silva ${ }^{1}$ and Lucia Moreno de Souza ${ }^{1}$
}

\begin{abstract}
The investigation of the karyotype of Oryzoborus maximiliani in living birds utilizing young feather pulp culture is described. The species karyotype was established as $2 \mathrm{n}=72$ with unequivocal identification of the sexual chromosome pair. Evolutionary considerations are raised.
\end{abstract}

\section{INTRODUCTION}

The species Oryzoborus maximiliani belongs to the family Emberizidae, subfamily Emberizinae, order Passeriformes. The genus Oryzoborus also includes the species $O$. crassirostris and $O$. angolensis. At the present moment, it is one of the most appreciated and valuable singing birds. It is found from Central America to Bolivia, Colombia and Brazil.

Scarcity in the natural habitat turned its multiplication in captivity important.

Like other species, it does not present sexual dimorphism and until males start to sing, special techniques are required for early identification of sex.

Cytogenetics is an inoffensive and efficient method to study the chromosomes of birds, in the order Passeriformes. Young birds can be sexed by viewing their sexual chromosomes. Phylogenetic and evolutionary studies can be carried out by viewing the entire chromosome complement.

According to Sick (1997) about 5739 of the 9702 species of birds of the world are represented by the order Passeriformes. Among birds cytogenetically analyzed, this order presents the greatest number of karyotyped species, reaching about 280 (Lucca and Rocha, 1992). According to these authors, the majority of them maintain a karyotypic likeness to each other both in number $(2 n=80)$ and chromosome morphology which is mainly of the subtelocentric type.

Karyotype studies of bird species not yet analyzed can offer important information towards a better knowledge of the mechanisms of evolution and of phylogenetic connection with the group.

Conventional staining of chromosomes allows for the identification of numbers and structure. Substrutures of the chromosomes, however, can only be shown by spe- cial banding techniques, a method not very successful in birds despite its use for 30 years.

The objective of the present study, is to determine chromosome characteristics of the species $O$. maximiliani, like number, morphology, identification of the sexual pair and aspects of the microchromosomes using young birds feather pulp cultures.

\section{MATERIAL AND METHODS}

Chromosome studies were carried out on 20 specimens of $O$. maximiliani of both sexes, aged between 9 and 10 days, obtained from private breeders of the State of Rio de Janeiro.

Chromosome preparations were obtained according to Shoffner (1974) with some modifications. Young feather pulp was cultured in an RPMI 1640 medium containing five drops of $0.0016 \%$ colchicine solution for $40 \mathrm{~min}$. Hypotonization was accomplished with $0.075 \mathrm{M} \mathrm{KCl}$ for $30 \mathrm{~min}$ followed by fixation with methanol/acetic acid (3:1). The material was analyzed by conventional staining with $3 \%$ Giemsa in phosphate buffer, pH 6.8, and photographed with film TMAX 100, Kodak film.

\section{RESULTS AND DISCUSSION}

The karyotype of $O$. maximiliani, here described for the first time, unlike that of most Passeriformes species, presented approximately 72 chromosomes.

The difference among macro- and microchromosomes in this species is distinct enough, the macrochromosomes being the first seven pairs in decreasing order of size, including the sexual pair.

This visible difference between macro- and micro- 


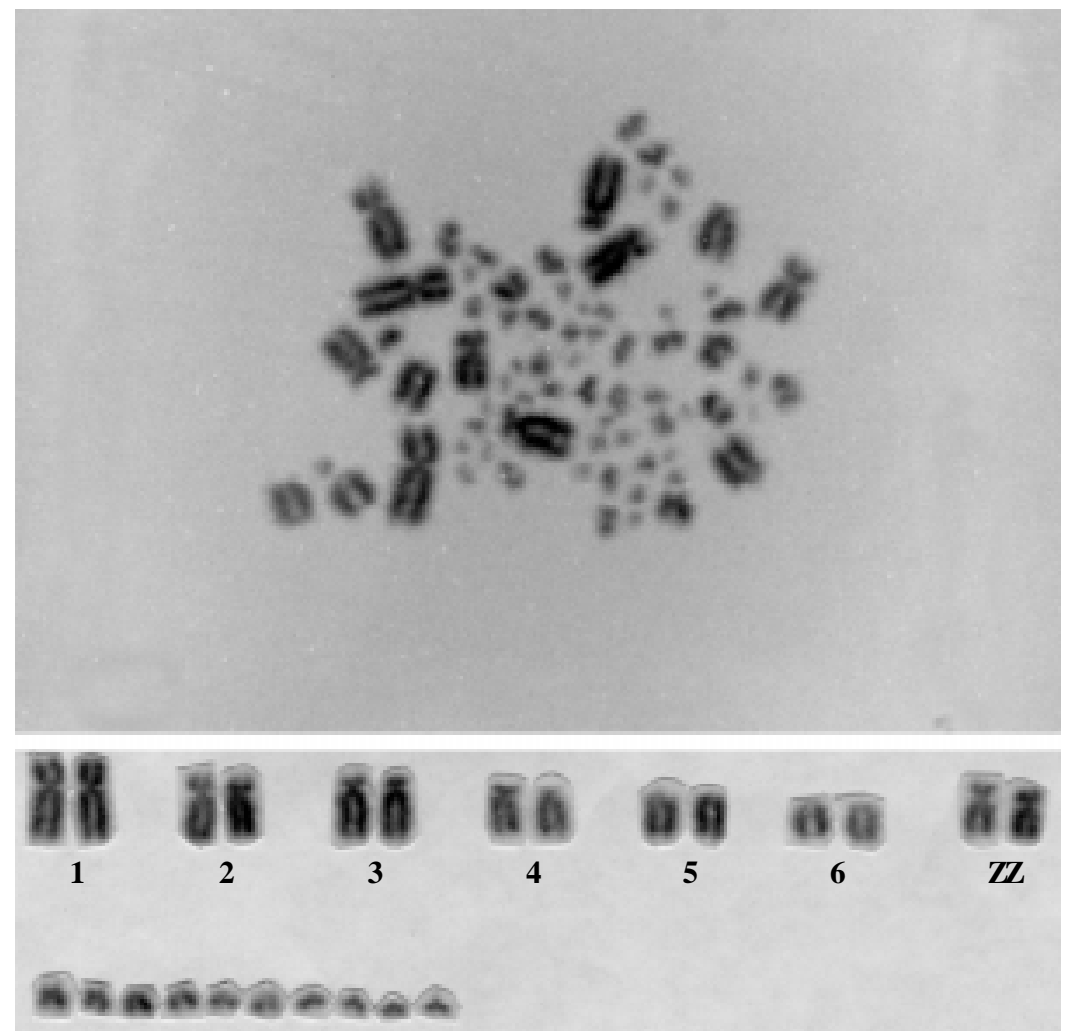

Figure 1 - Chromosomes of a male Oryzoborus maximiliani with a metaphase plate and partial karyogram.

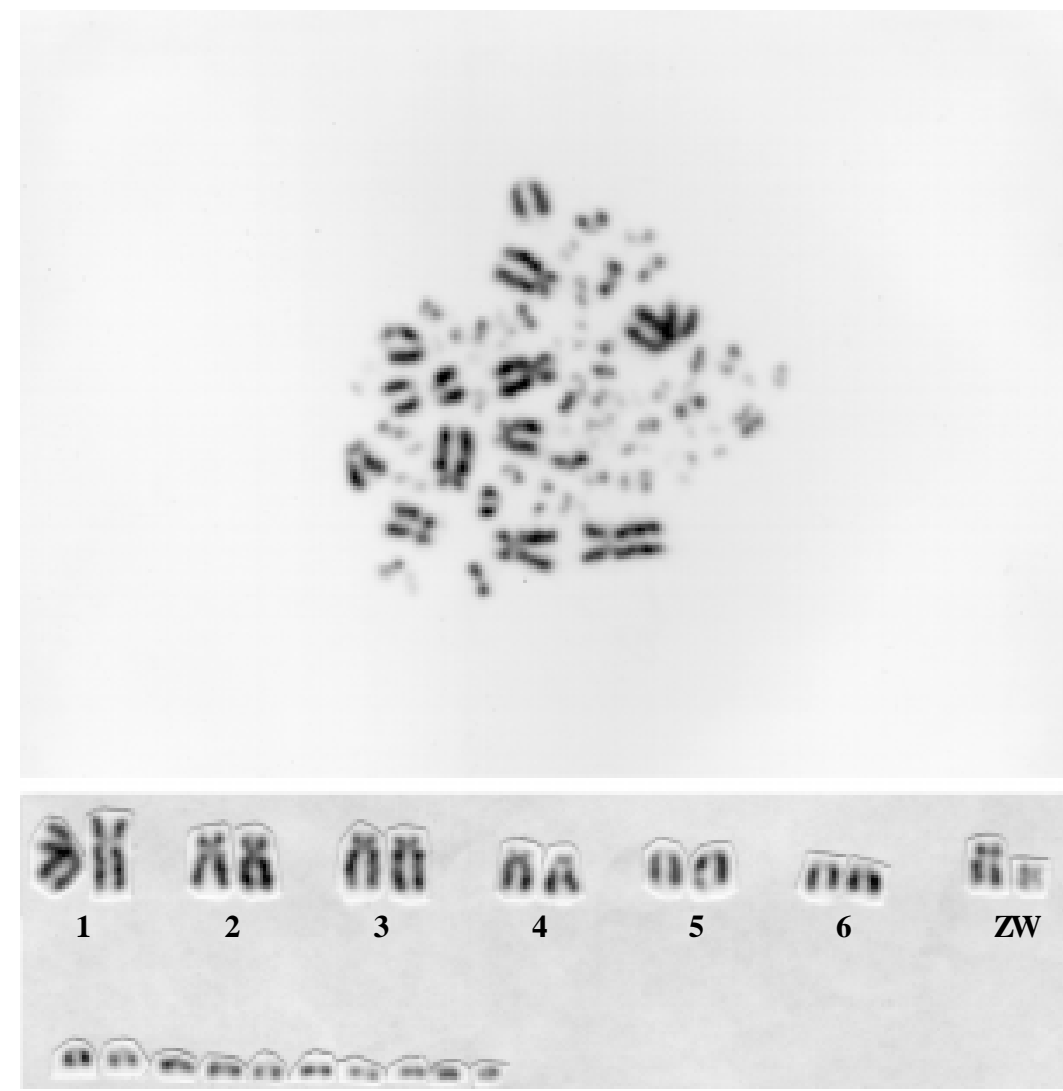

Figure 2 - Chromosomes of a female Oryzoborus maximiliani with a metaphase plate and partial karyogram. 
chromosomes could be construed as an evolutionary mechanism of this species of birds, by which the microchromosomes fuse forming macrochromosomes.

Among the macrochromosomes, the first couple is submetacentric, pairs 2, 3 and 4 are subtelocentrics and pairs 5 and 6 , acrocentrics. The chromosome $Z$ was identified as a submetacentric with a size comparable to that of the fourth pair (Figure 1) and the chromosome $\mathrm{W}$ a small metacentric of easy identification (Figure 2).

The microchromosomes are so numerous and often so small as to make it difficult to identify the centromeric position, a fact also reported by others for Passeriformes species (Lucca, 1974; Belterman and Boer, 1984; Lucca and Rocha,1985; Lucca and Waldrigues, 1985).

Cytogenetic studies of the order Passeriformes have up to now only relied on experiments requiring the sacrifice of the bird for studies with cells of bone marrow or embryonic eggs.

The present work made it possible to establish karyotypic patterns of the species $O$. maximiliani and to adapt the technique of short-cultured feather pulp of young birds, allowing investigations in living individuals. Feathers of young birds present an intense cellular proliferation which permits a better metaphase quality and a higher mitotic index, which is useful in reproduction programs of endangered species.

\section{ACKNOWLEDGMENTS}

The authors greatly thank Fundação de Amparo à Pesquisa do Estado do Rio de Janeiro (FAPERJ) for their financial support. Our gratitude is due to Mr. Ailton Milward for his essential assistance in providing the specimens for this experiment.

\section{RESUMO}

Foram estudados citogeneticamente vinte exemplares da espécie Oryzoborus maximiliani provenientes de criatórios do Estado do Rio de Janeiro. Foi aplicada a técnica de cultura de curta duração de polpa de penas jovens, permitindo a investigação nas aves vivas. O cariótipo da espécie foi estabelecido $(2 n=72)$ com identificação do par sexual. Considerações evolutivas são abordadas.

\section{REFERENCES}

Belterman, R.H. and Boer, L.E.M. (1984). The karyological study of 55 species of birds, including karyotypes of 39 species new to cytology. Genetica 65: 39-82.

Lucca, E.J. (1974). Cariótipos de 8 espécies de aves. Rev. Bras. Biol. 34: 387 392.

Lucca, E.J. and Rocha, G.T. (1985). Chromosomal polymorphism in Zonotrichia capensis (Passeriformes-Aves). Rev. Bras. Genet. VIII: 7178.

Lucca, E.J. and Rocha, G.T. (1992). Citogenética de Aves. Bol. Mus. Para. Emílio Goeldi, Sér. 8: 33-68.

Lucca, E.J. and Waldrigues, A. (1985). The karyotypes of nine species of Passeriformes. Egypt. J. Genet. Cytol. 14: 41-50.

Shoffner, R.N. (1974). The chromosomes of birds. In: The Cell Nucleus (Bush, H., ed.). Academic Press, New York.

Sick, H. (1997). Ornitologia Brasileira. Ed. Universidade de Brasília, Brasília, pp. 827.

(Received January 4, 2000) 
